\title{
Effect of UV-C Radiation on Egyptian Henbane (Hyoscyamus muticus L.) Callus Growth and Biochemical Components
}

\author{
Abdelrazik E. ${ }^{1}$; M. A. M. El-hamahmy ${ }^{2 *}$;. Abo-Elsoud ${ }^{3}$; Elham M. Ali ${ }^{4}$ and Akram A. Aboseidah ${ }^{1}$ \\ ${ }^{1}$ Department of Botany, Faculty of Science, Suez University, Suez, Egypt \\ ${ }^{2}$ Department of Agric. Botany, Faculty of Agriculture, Suez Canal University, Ismailia, 41522, Egypt \\ ${ }^{3}$ Department of Horticulture, Faculty of Agriculture, Suez Canal University, Ismailia, 41522, Egypt \\ ${ }^{4}$ Department of Environmental sciences, Suez University, Suez, Egypt
}

Received: 17/2/2019

\begin{abstract}
Physiological impact of different exposure periods (1, 2 and $3 \mathrm{~h})$ of UV-C (253.7 $\mathrm{nm})$ on alkaloids and hyoscyamine production in 21-days aged callus of Egyptian henbane was investigated. Results showed that the concentration of total alkaloids was increased by 2.7 and 2.3 times after exposure to UV-C for 2 or 3 h, respectively more than unstressed callus. Also, data of HPTLC revealed that $2 \mathrm{~h}$ exposed-callus accumulated the highest amount of hyoscyamine which similar to the amount in wild leaves but it was more 3.1 times than control. Increment of alkaloids concentration was attributed with high accumulation of non-enzymatic antioxidants as free amino acids, free phenolics and glutathione and increased of peroxidase and superoxide dismutase activity as well as reduction of $\mathrm{H}_{2} \mathrm{O}_{2}$ concentration. Also, $2 \mathrm{~h}$ exposed-callus to UV-C showed high expression of electrophoretic protein bands with molecular weights 109, 42 and $29 \mathrm{KDa}$. All exposure times to UV-C increased both fresh and dry weight of callus compared to unstressed one. Short exposure time of UV-C enhanced the amount of Chl. a and b in callus than other treatments. All exposure periods of UV-C decreased the concentration of carotenoids, anthocyanine, proline and total carbohydrates than control. Long exposure period of UV-C modified the callus cells shape by induction large spherical cells and lysigenous intercellular spaces. It can be concluded that $2 \mathrm{~h}$ exposure time of UV-C is effective treatment for enhancement both alkaloids and hyoscyamine content in callus of Egyptian henbane.
\end{abstract}

Keywords: Oxidative stress, enzymatic and non-enzymatic antioxidants, medicinal plants, phytochemicals, histology, protein electrophoresis

\section{INTRODUCTION}

Egyptian henbane (Hyoscyamus muticus L.) is an endemic Solanaceous plants in Egypt, is one of the rich source of alkaloid hyoscyamine (Mahran, 1967). Alkaloids are large nitrogenous compounds establish the defense mechanism that facilitate the interaction with the abiotic stressors and plant (Wang and $\mathrm{Wu}$, 2013).

Ultraviolet (UV) radiations included UV-C (200-280 nm) had a significant biological impact on plants according to radiation dose, exposure time and type of plant tissues (Katerova et al., 2013). UV elicitation is a potential technique for enhancement the secondary metabolites production from different medicinal or other plants. In this respect, elicitation of callus culture by UV increased the canthin-6-one alkaloid by 3.5 times and pyrrolidine by 1.5 times compared to unelicited callus of Eurycoma longifolia. Other secondary metabolites such as squalene and 5(hydroxymethyl)-2-furancarboxaldehyde increased in UV elicited callus of Eurycoma longifolia (Parikrama and Esyanti, 2014). Exposure period to UV had also different effect on the types of secondary metabolites. In this respect, $40 \mathrm{~min}$ of exposure time to UV (100$280 \mathrm{~nm}$ ) enhanced the salicylic acid concentration but 30 min of exposure time increased the scopolotein, caffeic acid and syringic acid in Althaea officinalis in vitro (Al-obaidi et al., 2014). Also, $10 \mathrm{~min}$ of exposure time to UV-C (254 nm) accumulated the highest trans-resveratrol concentration in 12 and 15

\footnotetext{
*Corresponding author e-mail: mhamahmy@yahoo.com
}

days-old callus of Vitis vinifera (Keskin et al., 2009). However, $5 \mathrm{~min}$ of exposure time to UV-C was effective for accumulation of acetyl-11-keto- $\beta$ boswellic acid (10-folds) and $\beta$-boswellic acid (7 folds) in callus of Boswellia serrate (Ghorpade et al., 2011). Moreover, long exposure period with low energy such as UV-B (12.6 and $25.3 \mathrm{~kJ} \mathrm{~m}^{-2}$ ) had potential effect on flavonoids such as vitexin, isovitexin and apigenin in 7-days callus aged jatropha (Jatropha curcas) that similar to or higher than those found in whole leaves (Alvero-Bascos and Ungson, 2012).

High dose or long exposure period of UV-C had deleterious effect on plant cells which accompanied with oxidative stress and production of different types reactive oxygen species (ROS). Plant cells had effective enzymatic systems such as peroxidase, catalase and superoxide dismutase and non-enzymatic compounds such as glutathione and anthocyanin which quench the ROS agents. ROS had deleterious effect on macromolecules function as chlorophylls, enzymes and ribonucleic acids which reduced the plant growth and development (Mittler, 2002). Therefore, re-homeostasis the physiological environment in plant cells under different abiotic stresses such as UV-C, may be enhance synthesizing and accumulation of alkaloids. To achieve that, investigation the effect of different exposure time of $\mathrm{UV}-\mathrm{C}$ radiation on alkaloids and hyoscyamine production in Egyptian henbane was done. 


\section{MATERIALS AND METHODS}

Seeds preparation and in vitro cultivation:

Wild seeds of Hyoscyamus muticus L. were collected from Saint Catherine peninsula and identified according to Tackholm (1974). Experiments were carried out at plant physiology and tissue culture laboratory, Botany Department, Faculty of Agriculture, Suez Canal University, Ismailia, Egypt. Seeds were dipped in $250 \mathrm{mg} \mathrm{l}^{-1}$ of gibberellic acid $\left(\mathrm{GA}_{3}\right)$ for $24 \mathrm{~h}$ at lab temperature $\left(25 \pm 0.5^{\circ} \mathrm{C}\right)$ to break dormancy (Alaghemand et al., 2013). Seeds were washed with tap water and surface-sterilized with $70 \%$ ethanol for 2 min, then in $25 \%$ commercial bleach (containing $5.25 \%$ sodium hypochlorite) with drops of tween- 80 for $20 \mathrm{~min}$ and finally rinsed 3 times with double distilled sterilized water. The sterilized seeds were cultured in hormone-free MS medium (Murashige and Skoog, 1962), supplemented with $7 \mathrm{~g} \mathrm{l}^{-1}$ agar and $15 \mathrm{~g}$ $1^{-1}$ sucrose and maintained at $25 \pm 1{ }^{\circ} \mathrm{C}$ under light condition (1,500 lux, $16 \mathrm{~h} /$ day) for germination. After germination, plantlets have been obtained for explants preparation.

\section{Explant culture and callus induction:}

Shoot tip (18 days-old) were excised and cultured on MS medium supplemented with different concentrations of benzyl amino purine (BAP) $(0.5 \mathrm{mg}$ $\left.1^{-1}\right)$ and naphthalene acetic acid (NAA) $(0.5,1.0$ and $2.0 \mathrm{mg} \mathrm{l}^{-1}$ ) for callus induction with 10 replicate. The cultures were incubated at $\left(25 \pm 1 \mathrm{C}^{\circ}\right)$ with $(16 / 8)$ light/dark cycle. After 4 weeks more suitable callus were selected for further work.

\section{UV treatment:}

After four weeks, callus were removed from vessels under aseptic condition and cut a suitable weights $(500 \mathrm{mg}$ ) and subculture on the same medium for further growth. Callus was irradiated using germicidal sterile lamps (Philips G 36 T6L), $2.5 \mathrm{~cm}$ tube diameter, $85 \mathrm{~cm}$ length, $41 \mathrm{~W}$ and $253.7 \mathrm{~nm}$ for 1 , 2 and $3 \mathrm{~h}$. The lamps were assembled $45 \mathrm{~cm}$ apart and the UV-C field area under the lamps was $60 \times 100 \mathrm{~cm}$ (Nigro et al., 1998). Callus cultures were incubated at $25 \pm 1{ }^{\circ} \mathrm{C}$ under light condition (1,500 lux, $16 \mathrm{~h} /$ day). After 21 days treatment callus was harvested and washed with distilled water to remove remains agar and dried by filter paper.

\section{Vegetative measurements:}

Forty pieces of callus fresh (FW) and dry weight (DW) after drying at $70^{\circ} \mathrm{C}$ until constant weight was recorded. Water content (\%) of callus was calculated using FW and DW values according to Henson et al. (1981).

\section{Biochemical determinations:}

Photosynthetic pigments (mg $100 \mathrm{~g}^{-1} \mathrm{FW}$ ) in callus (chl. a, b and carotenoids) were determined spectrophotometrically at 662, 644 and $440.5 \mathrm{~nm}$ (Arnon, 1949). Anthocyanins concentration (mg g ${ }^{-1}$ FW) was determined after digesting callus with $1 \%$ of $\mathrm{HCl}(\mathrm{v} / \mathrm{v})$ in methanol and kept overnight at $4^{\circ} \mathrm{C}$ (Lange et al., 1971), then centrifuged at $3000 \mathrm{rpm}$ for $10 \mathrm{~min}$ at $5^{\circ} \mathrm{C}$. The values are calculated as $\mathrm{E}_{535^{-}} 0.25$
$\left(\mathrm{E}_{650}\right) / \mathrm{g}$ FW. Total carbohydrates $\left(\mathrm{mg} \mathrm{g}^{-1} \mathrm{DW}\right)$ were determined after digestion by $5 \mathrm{ml}$ of $\mathrm{HCl}(2.5 \mathrm{~N})$ for 3 hours at $100^{\circ} \mathrm{C}$, then naturalized with sodium carbonate. Sample was made to volume of $10 \mathrm{ml}$ and then filtrated. $50 \mu \mathrm{l}$ was diluted to $1 \mathrm{ml}$ with distilled water. To each tube, $1 \mathrm{ml}$ of $5 \%$ phenol and $5 \mathrm{ml}$ of $96 \% \mathrm{H}_{2} \mathrm{SO}_{4}$ were added. After $10 \mathrm{~min}$, tubes were shaken at $25-30^{\circ} \mathrm{C}$ for $20 \mathrm{~min}$. Optical density was measured at $490 \mathrm{~nm}$ as reported in Hedge and Hofreiter (1962). Total protein (mg/g FW) was determined by Bradford method (Bradford, 1976) at $595 \mathrm{~nm}$. Proline concentration as $\mathrm{mg} \mathrm{g}^{-1} \mathrm{FW}$ was estimated with ninhydrin reagent as described by Bates et al. (1973), the red color intensity was measured at $520 \mathrm{~nm}$ against the toluene blank. Total glutathione ( $\mu \mathrm{mol} / \mathrm{mg}$ protein) was determined at $412 \mathrm{~nm}$ by 5-5'-Dithiobis (2nitrobenzoic acid) (DTNB) reagent (Griffith, 1980). For determination of total free amino acids and free phenols alcohol extraction of callus was prepared as Abdel-Rahman et al. (1975). Free phenolics (mg g ${ }^{-1}$ FW) were determined by a modified Folin-Ciocalteu method and measured at $650 \mathrm{~nm}$ according to Horwitz et al. (1970). Total free amino acids ( $\left.\mathrm{mg} \mathrm{g}^{-1} \mathrm{FW}\right)$ was estimated using the method of Rosen (1957) with ninhydrin reagent. The blue colored were measured against blank sample at $570 \mathrm{~nm}$. Hydrogen peroxide (mmol/g FW) was determined at $390 \mathrm{~nm}$ by the modified method according to Shi et al. (2007). Malondialdehyde ( $\left.\mu \mathrm{mol} . \mathrm{g}^{-1} \mathrm{FW}\right)$ determined by the thiobarbituric acid (TBA) reaction as described by Gallego et al. (1996). All spectrophotometric analyses were done using UV/VIS spectrophotometer, PG instrument Ltd, USA.

\section{Enzymatic antioxidants activity:}

Enzymes extract was prepared according to Urbanek et al. (1991). Catalase (CAT, E.C.: 1.11.1.6) activity was determined by measured the oxidation of $\mathrm{H}_{2} \mathrm{O}_{2}$ at $240 \mathrm{~nm}$ (Urbanek et al., 1991). The unit of CAT activity was defined as the amount of enzyme, which decomposes $1 \mathrm{mM} \quad \mathrm{H}_{2} \mathrm{O}_{2}$ per $\mathrm{mg}^{-}$ ${ }^{1}$ protein.minute. Peroxidase (POD, E.C.: 1.11.1.7) activity was estimated with $0.1 \% \mathrm{O}$-dianisidine and 0.2 M hydrogen peroxide at $430 \mathrm{~nm}$ (Urbanek et al., 1991). One unit of peroxidase activity was taken as the change of 1.0 unit of optical density per $\mathrm{mg}^{-1}$ protein.minute. Superoxide dismutase (SOD, E.C.: 1.15.1.1) activity was assayed by measuring its ability to inhibit reduction of nitro blue tetrazolium at $560 \mathrm{~nm}$ as described with (Beauchamp and Fridovich, 1971). One unit of enzyme activity represents the amount of enzyme required for $50 \%$ inhibition of NBT reduction.

\section{SDS-PAGE of soluble proteins:}

One dimensional SDS-PAGE gel electrophoresis based on the method of Laemmli (1970) was used to fractionate the soluble proteins in callus. Twenty milligrams of callus were dispersed in $1 \mathrm{ml}$ SDS $10 \%$ with $100 \mu \mathrm{l} \beta$-mercaptoethanol for $15 \mathrm{~min}$, then centrifuged at $11000 \mathrm{rpm}$ for $10 \mathrm{~min}$. Twenty $\mu \mathrm{l}$ of extraction were mixed with $20 \mu \mathrm{l}$ of SDS-loading sample buffer (SDS 4\%, $\beta$-mercaptoethanol 3\%, glycerol 20\%, Tris $\mathrm{HCl} \quad 50 \mathrm{mM} \quad \mathrm{pH} \quad 6.8$ and bromophenol blue traces), heated at $96^{\circ} \mathrm{C}$ for $3 \mathrm{~min}$ and 
$10 \mu \mathrm{l}$ aliquot was electrophoresed ( $10 \mu \mathrm{l}$ of protein/lane). The resolving and stacking gels were prepared according to the standard procedure of Davis (1964). The electrode buffer contained $50 \mathrm{mM}$ TRIS, glycine $0.384 \mathrm{M}$ and SDS $0.1 \%$. The protein bands were developed with Commassie Brilliant Blue R-250 dye $(0.2 \%$ solution, freshly prepared in $45 \%$ methanol, $10 \%$ glacial acetic acid and $45 \%$ distilled water) at room temperature overnight. The gel was photographed and made by scan apparatus as densitometric (optical density) analysis at $600 \mathrm{~nm}$ using standard maker protein (Pharmacia).

\section{Histological investigations:}

For longitudinal sections (15 $\mu \mathrm{m}$ thick), callus was fixed in formalin acetic acid (FAA), then dehydrated with ethanol series and cleared with ethanol-xylene. Then samples were embedded in paraffin wax at $45-55^{\circ} \mathrm{C}$ (Johansen, 1940). Sections were cut with steel blade on rotary microtome. The fixed sections were stained with Safranin O-Fast-green double stain. After staining, sections mounted in Canada balsam (Sass, 1961). Observation and photomicrographs were achieved using research microscope fitted with digital camera Staining Chart (NO.). For staining alkaloid, callus was macerated and stained with Dragendorff's reagent

\section{Alkaloids determination:}

To extract alkaloids, powdered dry callus was percolated overnight in methanol till complete exhaustion, then methanol was removed by distillation under pressure. Residue was stirred with $0.1 \mathrm{~N} \mathrm{HCl}$ and extracted with $\mathrm{CH}_{3} \mathrm{Cl}$. Chloroformic layer was washed with $0.1 \mathrm{~N} \mathrm{HCl}$ and discarded. The combined acidic layer was then rendered alkaline with $\mathrm{NH}_{4} \mathrm{OH}$ and extracted with $\mathrm{CH}_{3} \mathrm{Cl}$. Chloroformic layer was collected, then evaporated, and the final residue was dissolved in desired chloroform (Karawya et al., 1975). Total alkaloids concentration was determined by adding $5 \mathrm{ml}$ of bromocresol green solution (prepared by heating $69.8 \mathrm{mg}$ bromocresol green with $3 \mathrm{ml}$ of $2 \mathrm{~N} \mathrm{NaOH}$ and $5 \mathrm{ml}$ distilled water until completely dissolved and the solution was diluted to $1000 \mathrm{ml}$ with distilled water) and $5 \mathrm{ml}$ of phosphate buffer solution $(\mathrm{pH}$ 4.7) (prepared by adjusting the $\mathrm{pH}$ of $2 \mathrm{M}$ sodium phosphate $\left(71.6 \mathrm{~g} \mathrm{Na}_{2} \mathrm{HPO}_{4}\right.$ in $1 \mathrm{~L}$ distilled water) to 4.7 with $0.2 \mathrm{M}$ citric acid (42.02 g citric acid in $1 \mathrm{~L}$ distilled water) to a part of chloroform solution. The mixture was shaken and complex extracted with 1, 2, 3 and $4 \mathrm{ml}$ chloroform by vigorous shaking, the extract was then collected in a 10 $\mathrm{ml}$ volumetric flask and diluted with chloroform. Atropine standard solution was made by dissolving 1 $\mathrm{mg}$ of Atropine (Sigma) in $10 \mathrm{ml}$ distilled water (Ajanal et al., 2012). The absorbance of the complex in chloroform was measured at spectrum of $470 \mathrm{~nm}$ in UV-Spectrophotometer against the blank prepared as above but without Atropine.

\section{Determination of Hyoscyamine concentration:}

High-Performance Thin-Layer Chromatography (HPTLC) was performed on $20 \mathrm{~cm} \times 10 \mathrm{~cm}$ HPTLC silica gel $60 \mathrm{~F}_{254}$ plates (Merck) with a mobile phase consisting of chloroform : methanol : acetone : aqueous ammonia (25\%) $75: 15: 10: 1.6 \quad(\mathrm{v} / \mathrm{v} / \mathrm{v} / \mathrm{v})$. Hyoscyamine standard (Sigma) was diluted by chloroform to final concentration $20,40,60,80,120$, $160 \mu \mathrm{g} / \mathrm{ml}$. All samples and standards were applied to the plates by means of CAMAG Linomat 5 with dosing syringe $100 \mu$ las $7 \mathrm{~mm}$ bands with $10.5 \mathrm{~mm}$ distance between tracks, application X $15 \mathrm{~mm}$ and 13 $\mathrm{mm}$ application $\mathrm{Y}$ edges of plate and the application volume was 1-20 $\mu$ l for samples and 2-8 $\mu$ l for standard. Loaded HPTLC plates were developed to a distance of $50 \mathrm{~mm}$ in Camag Automatic Developing Chamber CADC 2 at room temperature. The development occurring in a two-steps (preconditioning with $10 \mathrm{ml}$ mobile phase for 5 minutes and development with $25 \mathrm{ml}$ mobile phase for 20 minutes) The plate was developed to a distance of $50 \mathrm{~mm}$ and dried for $5 \mathrm{~min}$ by a stream of warm air, then the plates derivatized with $200 \mathrm{ml}$ Dragendorff's reagent using Chromatogram Immersion Device. Then the plate was scanned and examined densitometry at $1=550 \mathrm{~nm}$ by means of CAMAGTLC Scanner 4 with slit dimension of $6 \times 0.30 \mathrm{~mm}$

\section{Statistical analysis:}

All data were statistically analyzed as randomized complete blocks design (Steel et al., 1997). Analysis of variance (one-way analysis; ANOVA) and means comparisons (Duncan's multiple range tests, $5 \%$ ) were performed using the MSTAT-C statistical pack-age (M-STAT, 1990).

\section{RESULTS}

Effect of UV-C on vegetative growth and total carbohydrates of callus:

All exposure periods of UV-C increased the fresh (FW) and dry (DW) weights of callus compared to control without significant differences among each other (Fig. 1a and b; Fig. 2a). The highest values of FW were detected after 1 and $2 \mathrm{~h}$ of exposure time with increment by 40.1 and $34.8 \%$ than control, respectively. DW was increased by 1.2 to 1.4 times in UV-C stressed callus than unstressed one. Water content \% was insignificantly differed among all treatments (Fig. 1c). Both UV-C exposure periods ( 1 and $2 \mathrm{~h}$ ) reduced the total carbohydrates content by 13.3 and $11.1 \%$ compared to un-treated callus but long exposure time gave similar concentration with control (Fig. 1d)

\section{Effect of UV-C on callus histology and alkaloids crystal distribution:}

$3 \mathrm{~h}$ of UV-C exposure time induced the large irregular spherical cells compared to ovate or oblong shape in other treatments and control (Fig. 2b). The same period gave the highest values of cell length and width as shown in Table (1) with increment by 3.4 and 3.2 times compared to control. Medium and long exposure time of UV-C induced the asymmetry of callus cells with lysigenous intercellular spaces compared to symmetry cells with schizogenous intercellular spaces in low exposure one and control. Abundance of orange-stained alkaloid crystals (Fig. 2c) inside cells were observed in all UV-C treated calli especially that exposed to $2 \mathrm{~h}$ of UV-C than control. 
00 alh $\square 2 \mathrm{~h} 03 \mathrm{~h}$

(A)

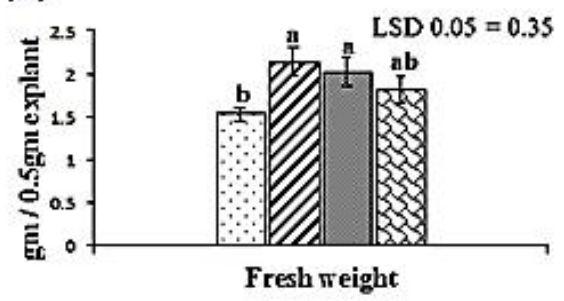

(c)

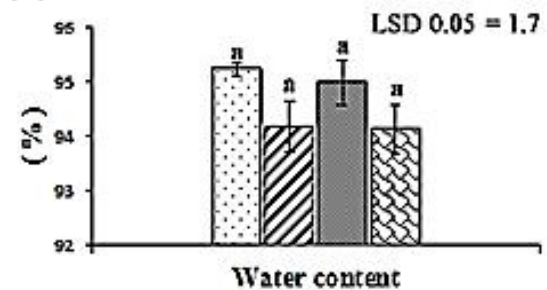

(B)

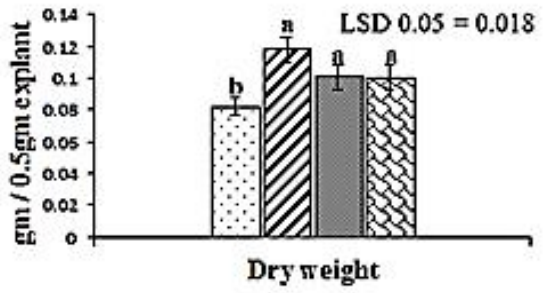

(D)

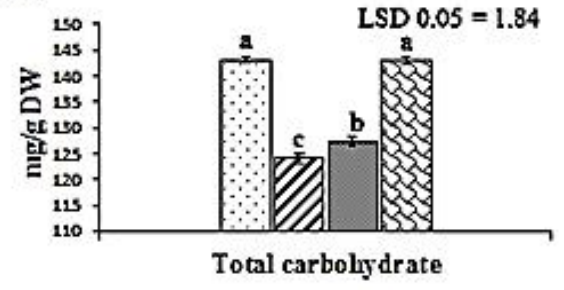

Fig. (1): Effect of different exposure periods of UV-C on fresh, dry weight, water content (\%) and total carbohydrate concentration of callus of $H$. muticus L., after 21 days

A

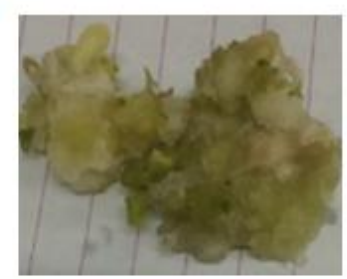

B

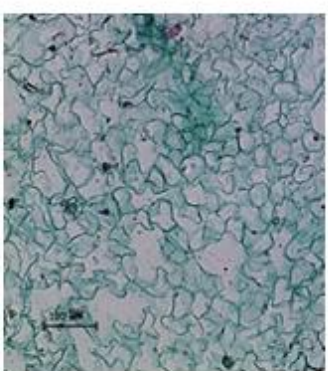

C

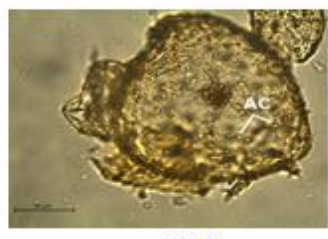

0.0
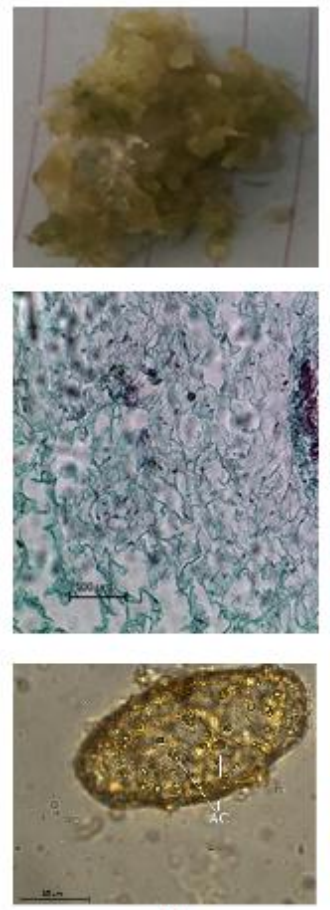

$1 \mathrm{~h}$
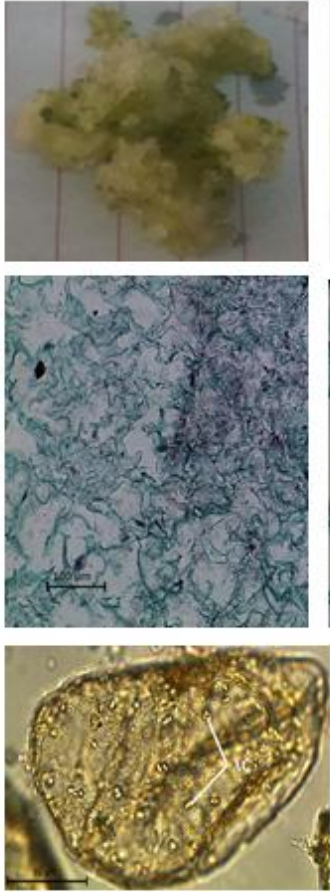

$2 \mathrm{~h}$
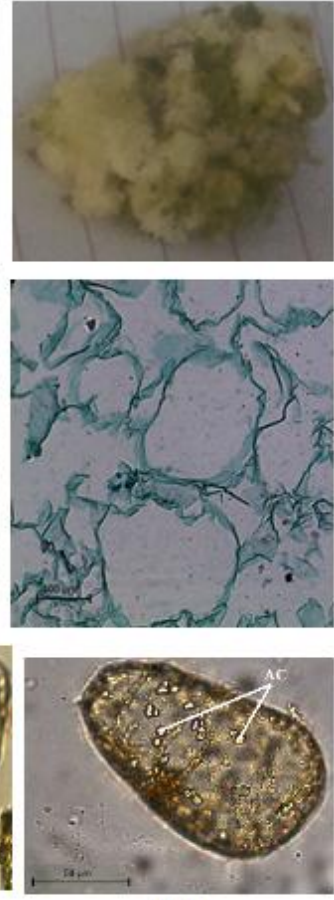

$3 \mathrm{~h}$

Fig. (2): Effect of different exposure periods of UV-C on growth (A), histology (B) and orange -stained alkaloid crystals distribution (C) in callus of H. muticus L., after 21 days; AC (Alkaloid crystals)

\section{Effect of UV-C on pigments:}

Short exposure period (1h) had stimulated effect on Chl. a and $\mathrm{b}$ content in callus (Fig. $3 \mathrm{a}$ and $\mathrm{b}$ ). The highest concentration of Chl. a and $\mathrm{b}$ (3.224 and 1.815 $\mathrm{mg} 100^{-1} \mathrm{mg} \mathrm{FW}$, respectively) was determined in $1 \mathrm{~h}$ exposed-callus with 14.4 and $10.9 \%$ of increment than control. Long exposure period of UV-C decreased both
Chl. a and b content. Both carotenoid and anthocyanin content were decreased in UV-C stressed-callus at all exposure times than control (Fig. $3 \mathrm{c}$ and d). $2 \mathrm{~h}$ of UV$\mathrm{C}$ exposed callus recorded the highest reduction of carotenoids by 1.8 and $3 \mathrm{~h}$ of UV-C exposed one gave the highest reduction of anthocyanin by 3.1 times compared to control. 
Table (1): Callus cells description after 21 days as affected by different periods of UV-C

\begin{tabular}{|c|c|c|c|c|c|}
\hline \multirow{2}{*}{ UV (h) } & \multicolumn{3}{|c|}{ Cell } & \multirow{2}{*}{$\begin{array}{c}\text { Symmetric of } \\
\text { cells }\end{array}$} & \multirow{2}{*}{$\begin{array}{c}\text { Intercellular } \\
\text { space }\end{array}$} \\
\hline & Shape & Length $\mu \mathrm{m}$ & Width $\mu \mathrm{m}$ & & \\
\hline 0.0 (control) & Regular ovate & 72 & 54 & Symmetric & Schizogenous \\
\hline 1 & Regular oblong & 72.7 & 50 & Symmetric & Schizogenous \\
\hline 2 & Irregular oblong & 58.2 & 36.4 & Asymmetric & Lysiogenous \\
\hline 3 & Irregular spherical & 242.8 & 171.4 & Asymmetric & Lysiogenous \\
\hline
\end{tabular}

口0 Dlh a2 h $83 \mathrm{~h}$

(A)

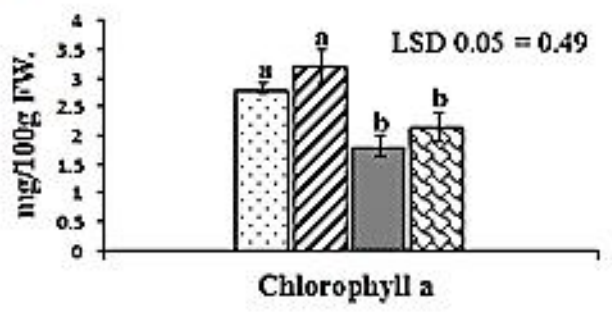

(c)

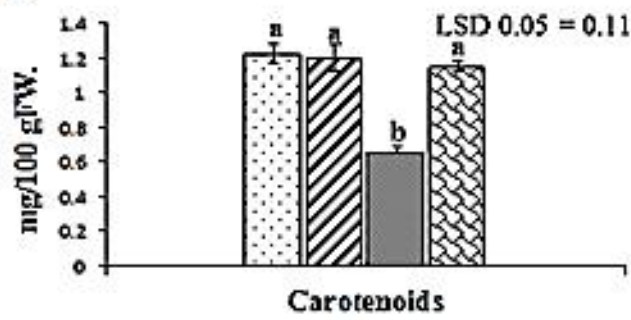

(B)

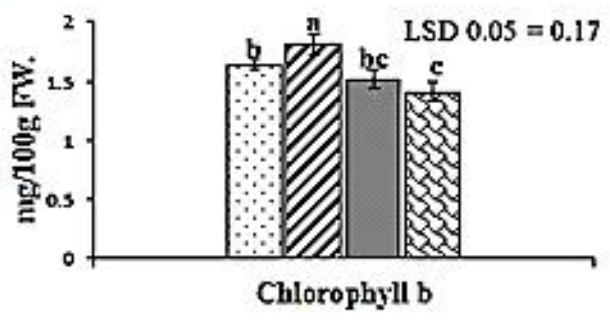

(D)

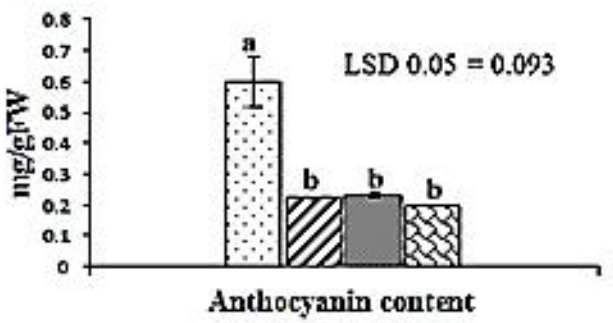

Fig. (3): Effect of different exposure periods of UV-C on pigments (Chl a, $\mathrm{Chl} \mathrm{b}$, carotenoid and anthocyanin) concentrations of callus of $H$. muticus L., after 21 days

\section{Effect of UV-C on non-enzymatic antioxidants and $\mathrm{H}_{2} \mathrm{O}_{2}$ :}

Glutathione concentration was increased at all exposure times of UV-C compared to control. $2 \mathrm{~h}$ of UV-C exposure time induced the highest content of glutathione $\left(4.87 \mu \mathrm{mol} \mathrm{mg}^{-1}\right.$ protein) with increment by $55.1 \%$ than control (Fig. 4a). Both 1 and $2 \mathrm{~h}$ of UV-C exposure time increased the concentration of free phenolics with increment by 18.5 and $9.7 \%$, respectively compared to control (Fig. 4b). The concentration of proline unchanged among UV-C periods or control (Fig. 4c). The concentration of $\mathrm{H}_{2} \mathrm{O}_{2}$ decreased in all UV-C treated callus compared to unstressed one. Insignificant differences were detected between UV-C treated callus for 2 and $3 \mathrm{~h}$ and untreated one (Fig. 4d).
Effect of UV-C on enzymatic antioxidant activity and malondialdehyde:

$2 \mathrm{~h}$ exposure period of UV-C induced the highest activity (1.185 unit $100 \mathrm{mg}^{-1}$ protein min.) of peroxidase (POD) with increment by 2.5 times than control (Fig. 5a). Activity of superoxide dismutase (SOD) was gradually increased by prolonging the exposure time of UV-C. $3 \mathrm{~h}$ exposure time of UV-C gave the highest activity of SOD (0.333 unit $\mathrm{mg}_{100 \mathrm{~g}^{-1}}$ protein min.) with increment by 2.2 time than control (Fig. 5b). Catalase (CAT) activity was reduced in all UV-C treatments compared to control (Fig. 5c). Although long period of UV-C exposure time enhanced the concentration of malondialdehyde (MDA), insignificant differences with other treatments were detected (Fig. 5d). 
(A)

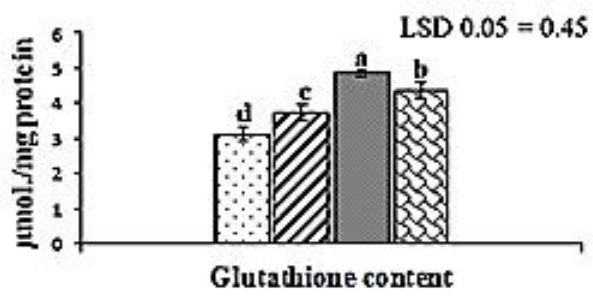

(c)

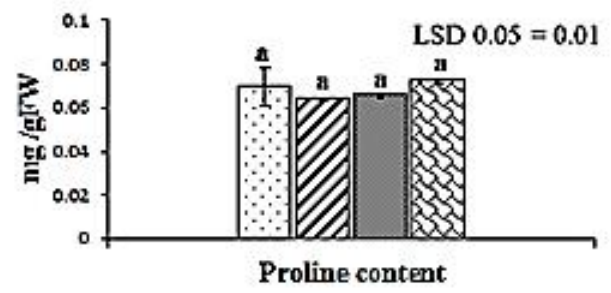

(B)

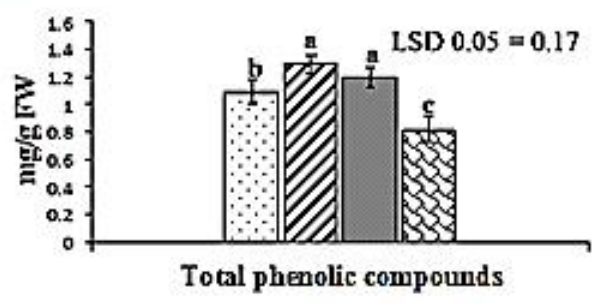

(D)

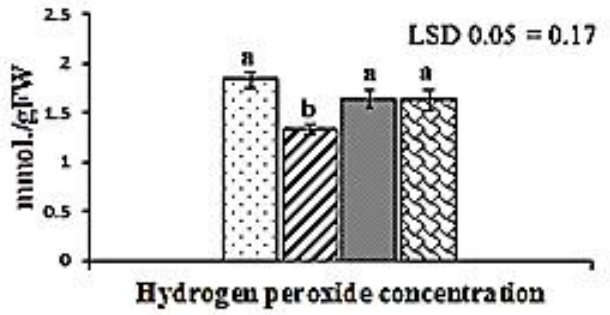

Fig. (4): Effect of different exposure periods of UV-C on glutathione (A), total phenolic compound (B), proline (C), and $\mathrm{H}_{2} \mathrm{O}_{2}$ (D) concentrations of callus of $H$. muticus L., after 21 days

(A)

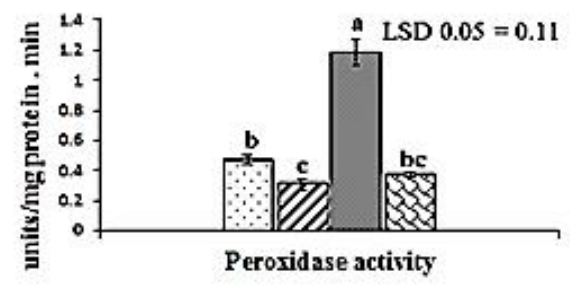

(C)

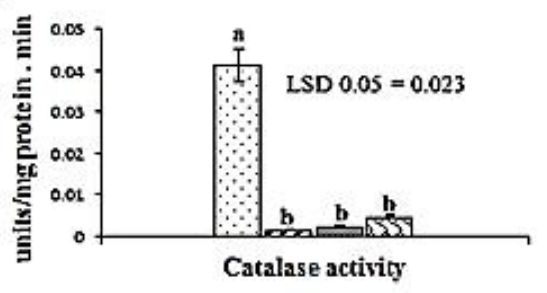

(B)

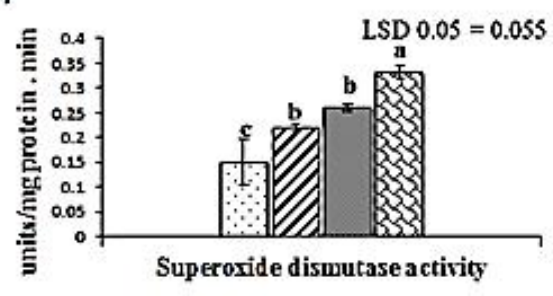

(D)

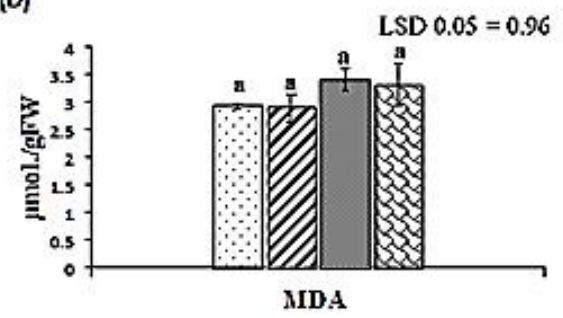

Fig. (5): Effect of different exposure periods of UV-C on POD (A), SOD (B), CAT (C) activity and MDA (D) content of callus of H. muticus L., after 21 days

\section{Effect of UV-C on nitrogenous compounds:}

Amino acid content was gradually increased with extending of UV-C exposure time. The highest amount of free amino acids $\left(3.04 \mathrm{mg} \mathrm{g}^{-1} \mathrm{FW}\right)$ was determined in $3 \mathrm{~h}$ of UV-C exposed callus with increment by $94.9 \%$ compared to control (Fig. 6a). Protein content was decreased in all UV-C treatments than control (Fig. 6b). The highest reduction (28.8\%) was observed in $2 \mathrm{~h}$ of UV-C exposed callus compared to control one. Exposure to UV-C for $2 \mathrm{~h}$ induced the highest concentration of total alkaloids $\left(44.86 \mathrm{mg} \mathrm{g}^{-1}\right.$ DW) with increment by 2.7 time followed by UV-C for $3 \mathrm{~h}$, which induced it by 2.3 time than control (Fig. 6c). Also, $2 \mathrm{~h}$ exposed-callus accumulated the highest amount of hyoscyamine $\left(2.523 \mathrm{mg} \mathrm{g}^{-1}\right.$ DW) which similar to the amount in wild leaves $(2.806 \mathrm{mg} \mathrm{g} \mathrm{DW})$ with 3.1 times of increment compared to control (Fig. 6d and Fig. 7). 


\section{Effect of UV-C on protein profile:}

12 well visible protein bands with different molecular weights from 240 to $10 \mathrm{KDa}$ were observed after protein electrophoresed on polyacrylamide gel (Fig. 8). Unique band with $64 \mathrm{KDa}$ was detected only in $1 \mathrm{~h}$ of UV-C exposed callus. Both bands with molecular weight 109 and $69 \mathrm{KDa}$ were appeared in all UV-C treatments and disappeared in unstressed callus. All electrophoretic protein bands had more expression values (as optical densities) than control. High expression values of protein bands with high and low molecular bands 240, 38, 17 and $10 \mathrm{KDa}$ was detected in $1 \mathrm{~h}$ of UV-C exposed callus. High expression values of protein bands with medium molecular weight 109 , 42 and $29 \mathrm{KDa}$ was detected in $2 \mathrm{~h}$ of UV-C exposed callus. Only protein band with molecular weight with $69 \mathrm{KDa}$ had high expression in $3 \mathrm{~h}$ of $\mathrm{UV}-\mathrm{C}$ exposed callus.

$\square 0 \quad \square \mathrm{hb} \quad \square 2 \mathrm{~h} \quad$ घ3 h

(A)

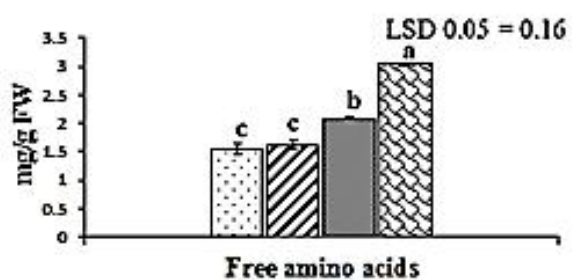

(B)

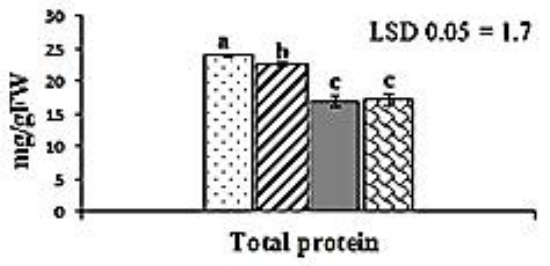

प0 alh $\square 2 \mathrm{~h}$ घ3 h arild leaves

(C)

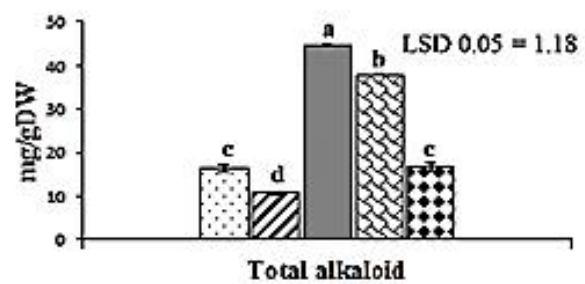

(D)

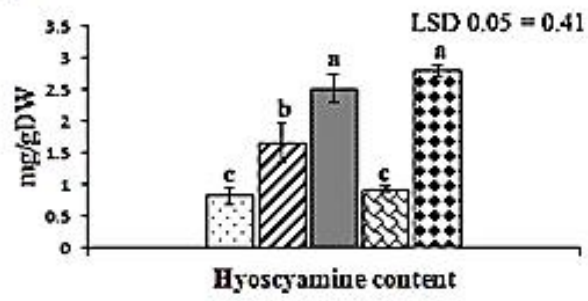

Fig. (6): Effect of different exposure periods of UV-C on free amino acids (A), protein (B), total alkaloid (C), and hyoscyamine (D) concentrations of callus of H. muticus L., after 21 days

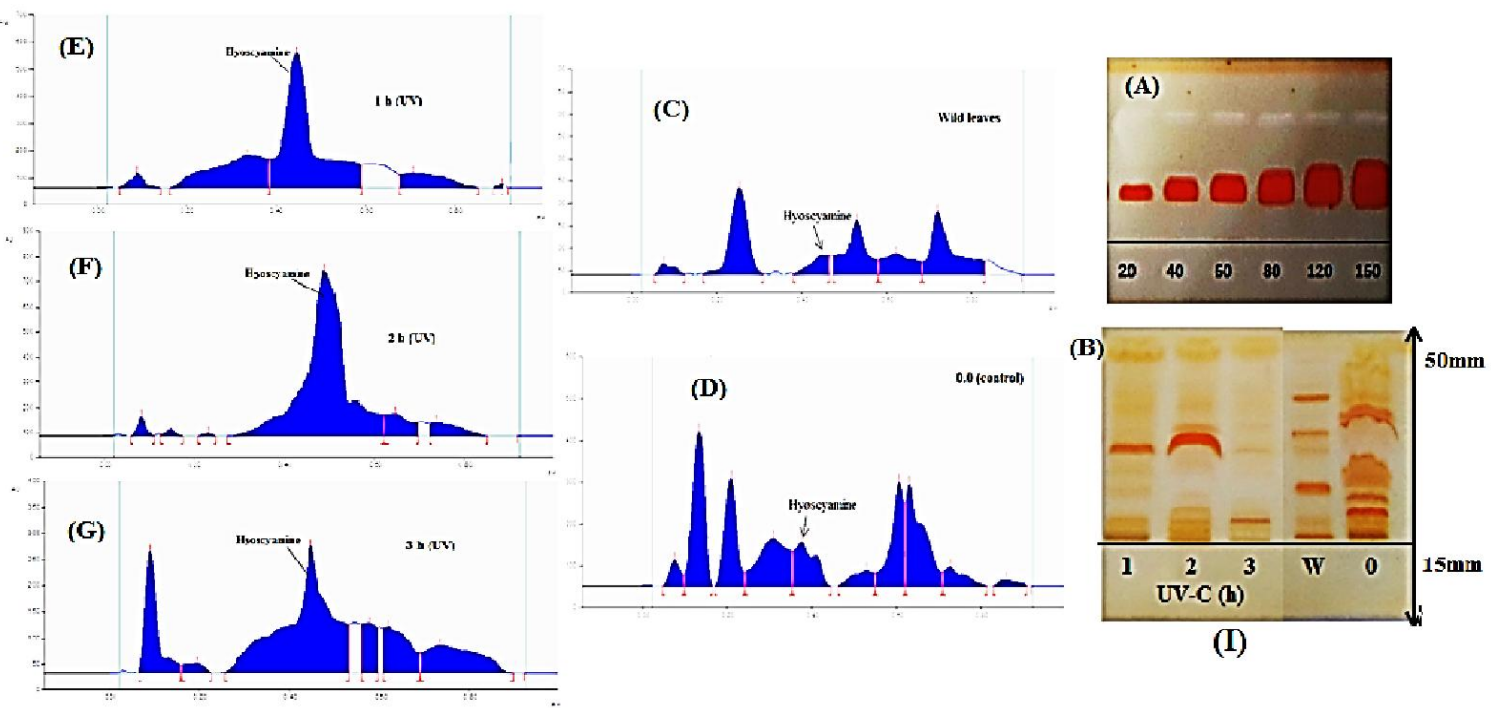

(II)

Fig. (7): Chromatogram of alkaloid fraction from (A) hyoscyamine standard solutions ( $\mu \mathrm{g} / \mathrm{ml})$ and (B) H. muticus callus. (II) Densitogram of alkaloid fraction from $H$. muticus callus recorded at $\lambda=550 \mathrm{~nm}$ after derivatisation with Dragendorff's reagent, (C) wild leaves, (D) unexposed callus extract, (E) $1 \mathrm{~h}$ UV-C (F) $2 \mathrm{~h}$ UV-C and (G) 3h UV-C exposed callus 


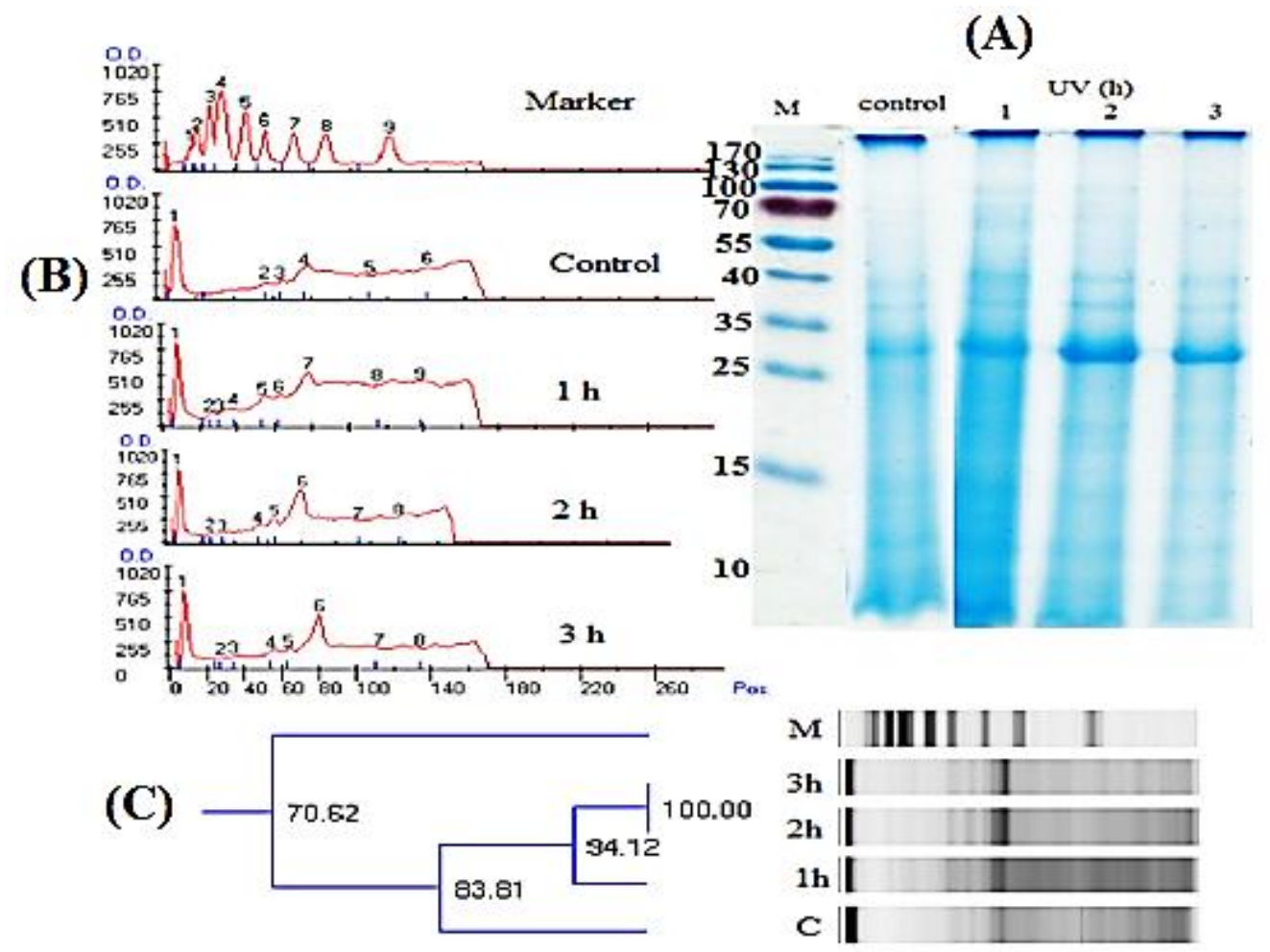

Fig. (8): SDS-PAGE of protein profile (A), optical densities of each protein band (B) and similarity (C) of each exposure period of UV-C of callus of $H$. muticus L., after 21 days

\section{DISCUSSION}

UV elicitation is a potential technique to enhance secondary metabolites production as alkaloids and terpenoids in callus of different plants such as Eurycoma longifolia (Parikrama and Esyanti, 2014) and grape (Cetin, 2014). Previous literatures reported that low doses of UV-C induced the production of different protective molecules in plant cells such as phytoalexins, pathogensis related proteins (chitinases, glucanase), flavonoides, phenolic acids, lignin, suberin, as well as the antioxidant enzymes such as catalase $(\mathrm{CAT})$, peroxidase (POD) and polyphenyl ammonia lyase (Hopkins and Huner, 2004).

Results reported herein showed that the increment of total alkaloids concentration by 2.7 and 2.3 times after exposure to UV-C for 2 or $3 \mathrm{~h}$, respectively compared to untreated callus as shown in Fig. (6c). Also, Data of HPTLC revealed that, $2 \mathrm{~h}$ exposed-callus accumulated the highest amount of hyoscyamine which similar to the amount in wild leaves with 3.1 times of increment compared to control (Fig. 6d and Fig. 7). These increment was attributed with high accumulation of fresh (FW) and dry (DW) weight of callus (Fig. 1a and b; Fig. 2a). Effect of UV on vegetative and physiological parameters of callus differed according to its type and exposure time (Cetin, 2014). This results in line with Manaf et al. (2016) who found that long exposure time to UV-B increased all growth parameters in Echinacea purpurea callus.
However, Al-obaidi et al. (2014) showed insignificant increment of both FW and DW of Althaea officinalis callus after exposure to UV-C for $30 \mathrm{~min}$ while short exposure time reduced both of them. In contrary, long exposure time to UV-C had deleterious effect on biomass of $28 \mathrm{~d}$-old callus of Eurycoma longifolia (Parikrama and Esyanti, 2014). Increment of callus FW or DW was not correlated with accumulation of carbohydrates, so UV-C treatment decreased the concentration of carbohydrates as Oraibi (2017) observed in both UV-C treated intact plants or callus of Moringa oliefera compared with control.

Exposure to UV-C was accompanied with increment of the concentration of free amino acids in callus. Previous literatures reported that amino acids used as precursors for synthesizing different important compounds in plant such as tryptophan which induced the growth stimulated phytohormone auxine or ornithine which synthesis the cell protective alkaloids (Hopkins and Huner, 2004).

Results demonstrated that Egyptian henbane may be depend on different non-enzymatic antioxidant system as defense mechanism to quench the reactive oxygen species. Exposure to UV-C increased the concentration of glutathione. Therefore, low concentration of $\mathrm{H}_{2} \mathrm{O}_{2}$ in UV-C stressed callus due to its reduction to water in the chloroplast by glutathione was found (Hopkins and Huner, 2004). The concentration of $\mathrm{H}_{2} \mathrm{O}_{2}\left(\begin{array}{llll}1.3 & -1.6 & \mathrm{mmol} \mathrm{g} & \mathrm{FW}\end{array}\right)$ in 
Egyptian henban callus was optimum to produce the high amount of alkaloid and normal callus cells. This result coordinated with Zacchini and De Agazio (2004) who reported that highly increment of $\mathrm{H}_{2} \mathrm{O}_{2}$ content induced a slight cellular damage in both upper and lower layers of Nicotiana tabacum callus cultures after 24 and 48 h UV-C treatment.

Increment of phenolics concentration in UV-C stressed callus was detected. This results were in line with Cetin (2014) who found that total phenolics content was increased in calli exposed to UV-C for 5 min after $24 \mathrm{~h}$ in grape. Accumulation of soluble phenolic compounds such as lignin accompanied with deposition in cell walls and intercellular space and by deposition of a lignin like material on the surface of UV-B- stressed callus of Camellia sinensis (Zagoskina et al., 2003). In contrary, severe and high doses of UVB decreased the phenolics content, as well as modified the oxidative damage of damiana in vitro plants (Soriano-Melgar et al., 2014). The concentration of phenolics differed according to UV-C irradiation distance, irradiation duration and incubation period as Cetin (2014) found in Vitis vinifera callus, so calli exposed to UV-C for $5 \mathrm{~min}$ with $30 \mathrm{~cm}$ distance apart after $24 \mathrm{~h}$ had the highest total phenolic content. Also, $2 \mathrm{~h}$ of exposure time to UV-B of Echinacea purpurea callus increased the total phenolics and the maximum increase in cell suspension was achieved by $4 \mathrm{~h}$ (Manaf et al., 2016).

Results reported herein revealed that proline content unchanged among all UV-C stressed callus or unstressed one. Result was disagreed with Oraibi (2017) who found that UV-B for $30 \mathrm{~min}$ was increased the proline concentration in Moringa oliefera callus compared to the control. However, UV-C treatment decreased the concentration of anthocyanin which contrary to Khatami and Ghanati (2011) who reported the significant increment of anthocyanin content in callus of Malva neglecta after UV irradiation compared with the control.

Exposure to UV-C increased the activity of both enzymatic antioxidant peroxidase (POD) and superoxide dismutase (SOD). These findings were in line with Soriano-Melgar et al. (2014) who cleared that SOD activity was increased after exposure to UV-B radiation for 2 or $4 \mathrm{~h}$ in damiana in vitro plants but POD activity had no significant differences with control. Also, Zacchini and Agazio (2004) showed that ascorbate peroxidase and glutathione reductase activity activities was increased in Nicotiana tabacum callus after UV-C irradiation. While, catalase (CAT) activity did not change. Also, 2 and $4 \mathrm{~h}$ exposure time of UV-B increased POD activity in Echinacea purpurea callus (Manaf et al., 2016). CAT activity was elevated in grapevine callus cultures after exposure to UV-B (Steel and Greer, 2005)

High expression of protein bands with molecular weights 109, 42 and $29 \mathrm{KDa}$ was found in 2 $\mathrm{h}$ exposed callus. This result was agreed with Parikrama and Esyanti (2014) who found highly expression of protein bands with molecular weight $37.5,40,50,51 \mathrm{kDa}$ that participate in synthesis of secondary metabolites responsible for farnesyl diphosphate (FDP) synthase enzyme, strictosidine synthase, geranyldiphosphate synthase, and ornithine decarboxylase, respectively.

\section{CONCLUSION}

Elicitation callus of Egyptian henbane with UV$\mathrm{C}$ for $2 \mathrm{~h}$ was effective for accumulated the highest amount of hyosyamine. Callus under UV-C treatment enhanced the free amino acids, free phenolics and glutathione content as well as increased the peroxidase and superoxide dismutase activity. UV-C treatment increased both fresh weight and dry weight with enhanced the amount of photosynthetic pigments.

\section{REFERENCES}

Abdel-Rahman, M., T. H. Thomas, G. J. Doss and L. Howell (1975). Changes in endogenous plant hormones in cherry tomato fruits during development and maturation. Physiologia plantarum, 34(1): 39-43.

Ajanal, M., M. B. Gundkalle and S. U. Nayak (2012). Estimation of total alkaloid in Chitrakadivati by UV-Spectrophotometer. Ancient science of life, 31(4): 198.

Alaghemand, A., M. Ghorbanpour and B. Moghaddasian (2013). The Role of Gibberellic Acid, Sulfuric Acid and Cold Stratification. Pharma and Life Sci, 2: 99-103.

Al-obaidi, H. K. M., B. Munim, A. Twaij and A. S. Mohammed-ameen (2014). "World Journal of Pharmaceutical Sciences Effect of UV light on production of medicinal compounds of Althaea officinalis L. in vitro," World J. Pharm. Sci., 6: 0-6.

Alvero-Bascos, E. M. and L. B. Ungson (2012). Ultraviolet-B (UV-B) radiation as an elicitor of flavonoid production in callus cultures of jatropha (Jatropha curcas L.). Philippine Agricultural Scientist, 95(4): 335-343.

Arnon, D. I. (1949). Copper enzymes in isolated chloroplasts. Polyphenoloxidase in Beta vulgaris. Plant physiology, 24(1): 1.

Bates, L. S., R. P. Waldren and I. D. Teare (1973). Rapid determination of free proline for waterstress studies. Plant and soil, 39(1): 205-207.

Beauchamp, C. and I. Fridovich (1971). Superoxide dismutase: improved assays and an assay applicable to acrylamide gels. Analytical biochemistry, 44(1): 276-287.

Bradford, M. M. (1976). A rapid and sensitive method for the quantitation of microgram quantities of protein utilizing the principle of protein-dye binding. Analytical biochemistry, 72(1-2): 248-254.

Cetin, E. S. (2014). Induction of secondary metabolite production by UV-C radiation in Vitis vinifera L. Öküzgözü callus cultures. Biological research, 47(1): 37.

Davis, B. J. (1964). Disc electrophoresis-II method and application to human serum 
proteins. Annals of the New York academy of sciences, 121(2): 404-427.

Gallego, S. M., M. P. Benavides and M. L. Tomaro (1996). Effect of heavy metal ion excess on sunflower leaves: evidence for involvement of oxidative stress. Plant Science, 121(2): 151159.

Ghorpade, R. P., A. Chopra and T. D. Nikam (2011). Influence of Biotic and Abiotic Elicitors on Four Major Isomers of Boswellic Acid in Callus Culture of Boswellia serrata' Roxb. Plant Omics, 4(4): 169.

Griffith, O. W. (1980). Determination of glutathione and glutathione disulfide using glutathione reductase and 2-vinylpyridine. Analytical biochemistry, 106(1): 207-212.

Hedge, J. E. and B. T. Hofreiter (1962). In carbohydrate chemistry 17 (Eds whistler RL and Be Millee, JN) Academic press. New York.

Henson, I. E., V. Mahalakshmi, F. R. Bidinger and G. Alagarswamy (1981). Genotypic variation in pearl millet (Pennisetum americanum L. Leeke), in the ability to accumulate abscisic acid in response to water stress. Journal of experimental botany, 899-910.

Hopkins, W. G. and N. P. A. Huner (2004). Introduction to Plant Physiology. $3^{\text {rd }}$ Edition. John Wiley and Sons, Inc. USA, pp: 576.

Horwitz, W., P. Chichilo and H. Reynolds (1970). Official methods of analysis of the Association of Official Analytical Chemists. Official methods of analysis of the Association of Official Analytical Chemists.

Johansen, D. A. (1940). Plant microtechique. McGrawHill Book Company, Inc.; London.

Karawya, M. S., S. M. Abdel-Wahab, M. S. Hifnawy and M. G. Ghourab (1975). Colorimetric and gas-liquid chromatographic determination of atropine-hyoscyamine and hyoscine (scopolamine) in solanaceous plants. JournalAssociation of Official Analytical Chemists, 58(5): 884-887.

Katerova, Z., D. Todorova, K. Tasheva and I. Sergiev (2012). Influence of ultraviolet radiation on plant secondary metabolite production. Genet Plant Physiol, 2(3-4): 113-144.

Keskin, N., B. Kunter, Ü. K. Yaşı, U Işını and U. Inkübasyon (2009). The effects of callus age, UV irradiation and incubation time on transresveratrol production in grapevine callus culture. Tarim Bilimleri Dergisi, 15(1): 9-13.

Khatami, F. and F. Ghanati (2011). Effects of UV irradiation on cell viability, anthocyanin, and flavonoid contents of callus-cultured Malva neglecta cells. ICLST, 3: 202-204.

Laemmli, U. K. (1970). Cleavage of structural proteins during the assembly of the head of bacteriophage T4. nature, 227(5259), 680.

Lange, H., W. Shropshire and H. Mohr (1971). An analysis of phytochrome-mediated anthocyanin synthesis. Plant Physiology, 47(5): 649-655.
Mahran, G. H. (1967). Medicinal plants. $1^{\text {st }}$ ed, pp: 431 Anglo Egyptian Bookshop. Cairo, Egypt.

Manaf, H. H., K. A. Rabie and M. S. A. El-Aal (2016). Impact of UV-B radiation on some biochemical changes and growth parameters in Echinacea purpurea callus and suspension culture. Annals of Agricultural Sciences, 61(2): 207-216.

Mittler, R. (2002). Oxidative stress, antioxidants and stress tolerance. Trends in plant science, 7(9): 405-410.

M-STAT (1990). A microcomputer program for the design, management and analysis of agronomic research experiments. Michigan State University, EL.

Nigro, F., A. Ippolito and G. Lima (1998). Use of UV$\mathrm{C}$ light to reduce Botrytis storage rot of table grapes. Postharvest Biology and Technology, 13(3): 171-181.

Oraibi, A. G. (2011). Investigation on the Effects of UV Radiation on Physiological Characteristics of Moringa oleifera Lam. in vitro and in situ. Biotechnol. J. Int., 19(4), 1-8.

Parikrama, R., and R. R. Esyanti (2014). Effect of UV Elicitation on Callus Growth, Alkaloid and Terpenoid Contents in Eurycoma longifolia Jack. Int'l J. Adv. Chem. Engg. Biolog. Sci, 1(1): 12-15.

Rosen, H. (1957). A modified ninhydrin colorimetric analysis for amino acids. Archives of biochemistry and biophysics, 67(1): 10-15.

Sass, J. E. (1961). Botanical Microtechnique. Third edition. The IOWA State University Press. Amess. Iowa.

Shi, Q., F. Ding, X. Wang and M. Wei (2007). Exogenous nitric oxide protect cucumber roots against oxidative stress induced by salt stress. Plant Physiology and Biochemistry, 45(8): 542-550.

Soriano-Melgar, L. D. A. A., L. Alcaraz-Meléndez, L. C. Méndez-Rodríguez, M. E. Puente, F. Rivera-Cabrera and T. Zenteno-Savín (2014). Antioxidant responses of damiana (Turnera diffusa Willd) to exposure to artificial ultraviolet (UV) radiation in an in vitro model; part ii; UV-B radiation. Nutricion hospitalaria, 29(5): 1116-1122.

Steel, C. C., and L. A. Greer (2005). Catalase activity and susceptibility of grapevine callus culture (cv. Cabernet Sauvignon) to Botrytis cinerea infection: Effects of UV-B exposure. Vitis, 44(3): 149-150.

Steel, R. G. D., J. H. Torrie and D. A. Dickey (1997). Principles and procedures of statistics: a biometrical approach, $3^{\text {rd }}$ ed. (McGraw-Hill: New York).

Täckholm, V. (1974). Student's Flora of Egypt. Cairo University Press, Cairo, 888 pp.

Urbanek, H., E. Kuzniak-Gebarowska and K. Herka (1991). Elicitation of defense responses in bean leaves by Botrytis cinerea polygalacturonase. Acta Physiologiae Plantarum (Poland), 13:43-50. 
Wang, J. W. and J. Y. Wu (2013). Effective elicitors and process strategies for enhancement of secondary metabolite production in hairy root cultures. In Biotechnology of Hairy Root Systems (pp. 55-89). Springer, Berlin, Heidelberg.

Zacchini, M. and M. de Agazio (2004). Spread of oxidative damage and antioxidative response through cell layers of tobacco callus after UV-
C treatment. Plant Physiology and Biochemistry, 42(5): 445-450.

Zagoskina, N. V., G. A. Dubravina, A. K. Alyavina and E. A. Goncharuk (2003). Effect of ultraviolet (UV-B) radiation on the formation and localization of phenolic compounds in tea plant callus cultures. Russian journal of plant physiology, 50(2): 270-275.

$$
\begin{aligned}
& \text { تأثير الأشعة فوق البنفسية على نمو الكالس والمركبات البيوكيميائية في نبات السكران المصري }
\end{aligned}
$$

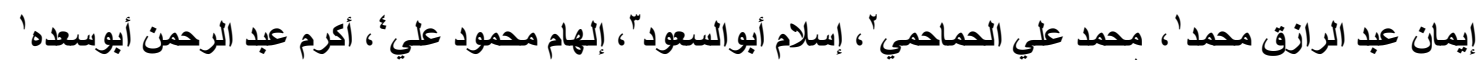

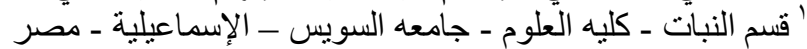

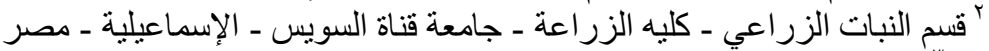

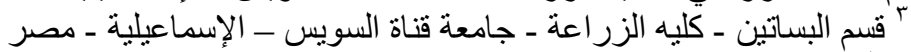

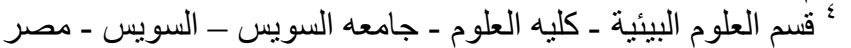

تم دراسة التأثير الفسيولوجي لفترات التعرض للأثعة فوق البنفسجية (ساعة ـ ساعثين - ثناث ساعات) علي إنتاج

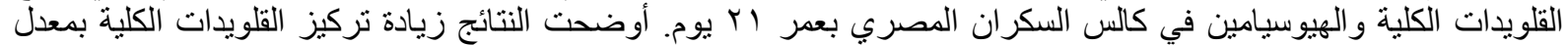

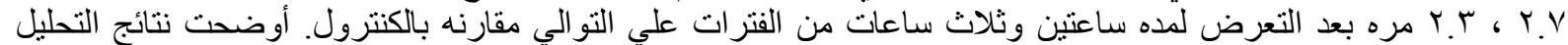

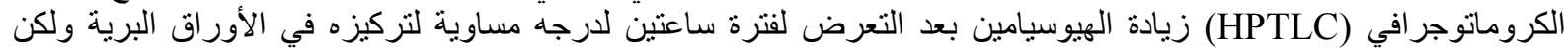

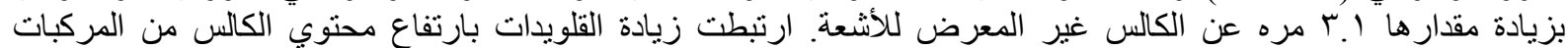

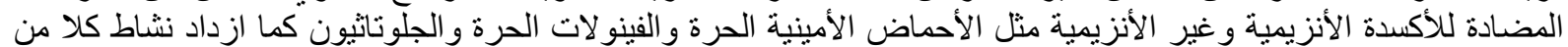

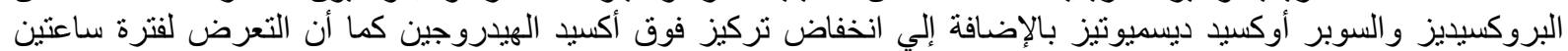

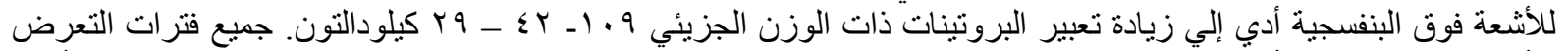

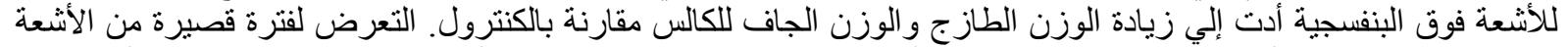
فوق البنفسية (ساعة) أدي لزيادة تركيز الكلوروفيل أ و ب مقارنه بباقي المعاملات. كما أدت جميع فترات التهات التعرض للأشعة فوق

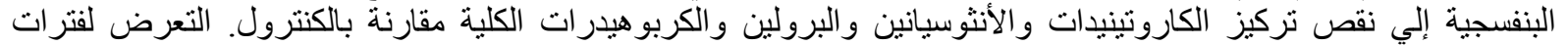
طويلة للأشعة فوق البنفسية أدت لتحور ات نسيجية في الكالس حيث أدت لزيادة استدارة وكبر حجم الخلايا وظهور المسافات

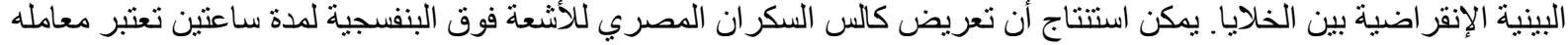

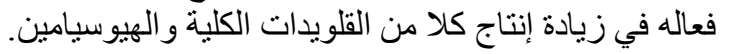

